\title{
"Clinically Relevant Patterns of Cardiovascular Comorbidities in Patients with COPD: Do They Matter at All?"
}

\author{
Borislav Božanić1,4, Milan Radović1,2,4, Ivana Stanković1,4, Svetlana Apostolovićn ${ }^{3,4}$, \\ Tatjana Pejčić1 ${ }^{1,4}$, Zorica Ćirić1,4, Lidija Risitić1 ${ }^{1,4}$, Milan Rančić1,4 \\ ${ }^{1}$ Clinic for Pulmonary Diseases, Clinical Center Niš, Serbia \\ ${ }^{2}$ Clinic for Thoracic Surgery, Clinical Center Niš, Serbia \\ ${ }^{3}$ Clinic for Cardiovascular Diseases, Clinical Center Niš, Serbia \\ ${ }^{4}$ University of Niš, Faculty of Medicine, Niš, Serbia
}

\section{SUMMARY}

The association of chronic obstructive pulmonary disease and cardiovascular disease was observed during the study of the systemic effects of this disease. Among these patients, the incidence as well as the mortality from cardiovascular disease are significantly higher, while the reduction of cardiovascular risk is an important target for the reduction of the overall mortality from COPD.

The complex pathophysiological mechanisms of the interaction of the respiratory and cardiovascular system during COPD exacerbation have not yet been sufficiently studied, but their clinical manifestations are an increasing challenge within modern diagnostics and therapy. Studies have shown that intensification of systemic inflammatory response in acute exacerbation of COPD results in endothelial dysfunction, activation of atherosclerotic plaques, increased susceptibility to rupture and thrombus formation, which is indirect but very significant cause of acute cardiovascular events.

Acute exacerbations of COPD can be the triggers of an acute cardiovascular event; however, they can be triggered by previous cardiovascular events as well. Despite an improved diagnostic-therapeutic procedure, this two-way association often remains unrecognized. The effect of COPD treatment on the coexisting vulnerability of the cardiovascular system is still not fully understood.

Despite the reliable evidence confirming the link between COPD and cardiovascular disease, modern therapeutic options for targeted treatment of these diseases are still in the testing phase, with no more relevant randomized clinical trials in this field. The first results of the SUMMIT study promise a more appropriate treatment of these patients.

Key words: chronic obstructive pulmonary disease, cardiovascular disease, inflammation

Corresponding author:

Borislav Božanić

E-mail: borislavbozanic@gmail.com 


\section{INTRODUCTION}

Chronic obstructive pulmonary disease (COPD) is a respiratory disease characterized by the presence of irreversibly progressing chronic respiratory symptoms as a result of airflow limitation (bronchial obstruction) and enhanced local and systemic inflammatory response to respiratory irritants of which the most significant is inhaled tobacco smoke during active cigarette smoking (1). It is manifested in the form of chronic bronchitis and emphysema, later associated with pulmonary hypertension. The chronicity of the disease is reflected in the progressive decline in pulmonary function resulting from narrowing of the airways, fibrosis and increased production of mucus, on the one side, and destruction of the pulmonary parenchyma, loss of elasticity and disturbance of gas exchange, on the other side. Described changes are the result of respiratory tract inflammation triggered by infectious agent, virus or bacteria, or an environmental factor (2-3), whereas the associated cardiovascular disease can be a deterioration factor of the underlying disease (4).

Epidemiological data indicate a strong association between bronchial obstruction and coronary artery disease (CAD), suggesting that patients with COPD should have a higher risk of developing CAD, as well as the opposite (5). The association of COPD and cardiovascular disease was observed during the study of systemic consequences of COPD. The diagnosis of COPD significantly increases the risk of cardiovascular disease: coronary artery disease, angina pectoris and myocardial infarction, stroke and congestive heart failure (6). Keeping this in mind, it is not surprising that sometimes more than $50 \%$ of patients hospitalized due to acute exacerbation of COPD have some of the previously listed cardiovascular comorbidities (7). On the other hand, the existence of common cardiovascular risks leads to a higher incidence of COPD. Among patients with COPD, there is a significantly higher incidence, but also the mortality from cardiovascular disease, while cardiovascular risk reduction represents an important field for the reduction of the overall mortality from COPD (8).

The complex pathophysiological mechanisms of the interaction of the respiratory and cardiovascular system during COPD exacerbation have not yet been sufficiently studied, but their clinical mani- festations are an increasing challenge within modern diagnostics and therapy.

\section{Common risk factors}

Invariable risk factors, such as gender and age, are associated with an increased mortality in COPD, while the diagnosis of COPD increases the 10-year cardiovascular risk in people over 55 years of age. Significantly higher cardiovascular morbidity was observed even among the younger and female population with the diagnosis of COPD (9). The most significant cardiovascular risk factors associated with COPD are cigarette smoking and age (10).

Metabolic syndrome is often present in patients with COPD, while low body mass index (BMI) is associated with worse prognosis (11-13). Low BMI is associated with a higher intensity of systemic inflammation, which is a more significant cause of cardiovascular comorbidity than obesity. Further studies are needed to determine the positive effects of higher BMI in patients with advanced stages of COPD, on the one hand, and the effect of obesity as cardiovascular risk in patients at the initial stage of COPD (14).

Arterial hypertension, dyslipidemia and diabetes represent diseases for themselves, but they are also significant factors for cardiovascular disease and COPD (15). Diabetes appears to be independently associated with a reduction in pulmonary function, while obesity impairs the mechanics of ventilation (16).

Therefore, the association of COPD and cardiovascular disease is a consequence of the existence of common risk factors, as well as the reciprocal interaction of these factors. However, the concomitant cardiovascular disease in COPD is now increasingly mentioned as part of the cardiopulmonary continuum, rather than as a simple consequence of the joint action of common risk factors. Complex cardio-respiratory interactions identified in recent years are based on the systemic inflammation process (17).

\section{Etiopathogenic significance of chronic inflammation}

Pathogenetic mechanisms significant for clinical manifestations of COPD and cardiovascular comorbidities still remain not fully understood. It is 
considered that common risk factors cause an uncontrolled chronic systemic inflammatory response that affects endothelium of blood vessels, mucosa of the bronchial tree and pulmonary paren- chyma, and that certain pathophysiological mechanisms during the onset and development of COPD directly affect the function of the heart, revealing CAD $(18,19)$ (Figure 1).
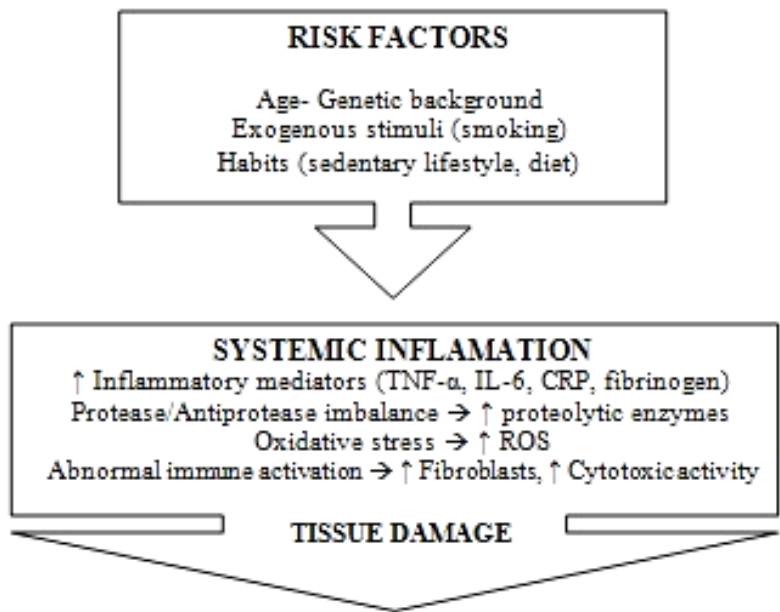
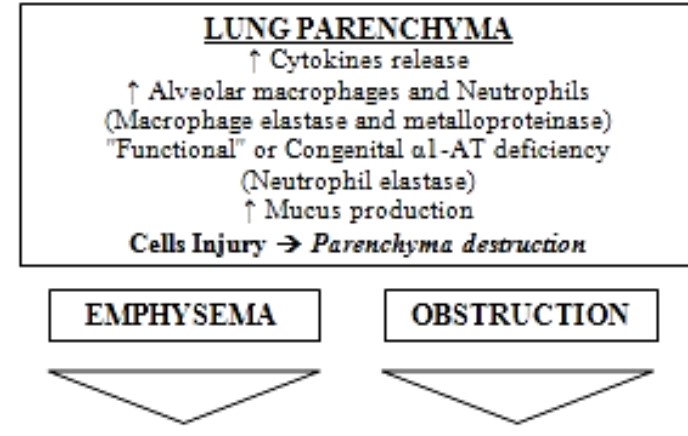

Chronic Obstructive

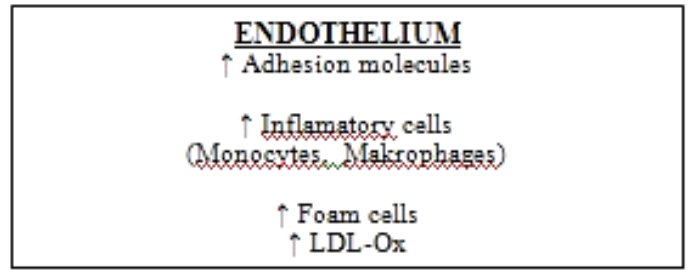

ATHEROSCLEROSIS

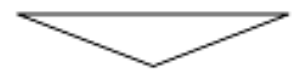

Coronary Artery Disease

Figure 1. Common pathogenic mechanisms of chronic obstructive pulmonary disease and coronary artery disease

TNF- $\alpha$, tumor necrosis factor alpha; IL-6, interleukin-6; CRP, C-reactive protein; ROS, reactive oxygen species; $\alpha 1$-AT, Alpha-1 antitrypsin; LDL-Ox, oxidized low-density lipoproteins.

There is a strong association between acute and chronic lung insufficiency, inflammation, peripheral vascular disease, acute vascular events, and endothelial dysfunction (20). COPD is characterized by chronic inflammation, and the extent of inflammation correlates with the severity of the disease. Chronic inflammation is associated with a systemic inflammatory response that involves the activation of acute phase reactants, the presence of inflammation mediators in the circulation, bone marrow stimulation resulting in an increased number of leukocytes and platelets, activation of circulating leukocytes and vascular endothelium (21).

Systemic inflammatory response affects the function of almost all organ systems, but this is particularly expressed on the vascular system. Inflammation at the level of the respiratory system triggers an inflammatory cascade that disrupts the function of the vascular system, which further has negative repercussions on the function of the respi- 
ratory system and thus leads to circulus vitiosus. This results from inflammatory mediators production in the respiratory tract and pulmonary parenchyma (C-reactive protein (CRP), fibrinogen, reactive oxygen radicals, cytokines, chemokines) which are directly released in blood and then distributed to other organic systems activating different cascades of the inflammatory response. Tumor necrosis factor $\alpha$ (TNF- $\alpha$ ) plays a central role in the chronic inflammation process, and it is also involved in the activation of secondary mediators, including CRP and proinflammatory cytokines (the most significant are interleukins 6, 7 and 8) (22).

Activation of circulatory lymphocytes and vascular endothelium causes the progression of the atherosclerosis process, i.e. cardiovascular events, which are predominant factors of morbidity and mortality in COPD. Studies have shown that inten- sification of systemic inflammatory response in acute exacerbation of COPD results in endothelial dysfunction, activation of atherosclerotic plaques, increased susceptibility to rupture and thrombus formation, which is indirect, but very significant cause of acute cardiovascular events (23).

\section{Clinical significance}

Taking into account the anatomical and functional relationship between the heart and the lungs, dysfunction of one of these organs implies the consequences on the other. Considering the fact that in one half of the population over the age of 65 , three or more chronic non-communicable diseases are most often registered, there is a high likelihood that CAD and COPD coexist in most cases (24-27) (Table $1)$.

Table 1. Overview of demographic characteristics of patients with COPD with the prevalence of the coexisting coronary heart disease

\begin{tabular}{c|c|c|c|c}
\hline \hline $\begin{array}{c}\text { Number of patients } \\
\text { (No) }\end{array}$ & $\begin{array}{c}\text { Average age } \\
\text { (years) }\end{array}$ & $\begin{array}{c}\text { Proportion of males } \\
\mathbf{( \% )}\end{array}$ & $\begin{array}{c}\text { Prevalence od CAD } \\
\mathbf{( \% )}\end{array}$ & Reference of study* \\
\hline 3183 & 71 & 70 & 8,5 & $(25)$ \\
\hline 1659 & 66 & 89 & 30,2 & $(26)$ \\
\hline 527 & 68 & 84,9 & $12,2-18,1$ & $(27)$ \\
\hline 351 & 58 & 42 & 59 & $(31)$ \\
\hline \hline
\end{tabular}

* data presented as reference number listed in references

COPD - chronic obstructive pulmonary disease; CAD - coronary artery disease

According to the guidelines of the Global Initiative for Chronic Obstructive Lung Disease (GOLD), the clinical diagnosis of COPD should be considered for each patient with chronic respiratory symptoms (dyspnea with or without chronic cough, with sputum production) and a positive history of exposure to risk factors (1). Considering the fact that concomitant presence of various pathological states and processes interferes with the diagnostic procedure and mask the basic clinical manifestations, especially during exacerbation of the disease, establishing of COPD diagnosis may be difficult.

The clinical picture of CAD is often masked by undefined symptoms that also correspond to the symptoms of COPD. Breathing difficulty, tightness and occasional pain in the chest are present in both $\mathrm{CAD}$ and acute exacerbation of COPD, so the origin of symptomatology is often misinterpreted (28). Sudden myocardial ischemia can also be manifested as a syndrome of difficulty breathing without angina pain. Some authors point out the fact that in $20-30 \%$ of patients with COPD there is an electrocardiographic finding of an earlier myocardial infarction, with only one half being diagnosed and treated in a timely manner (29).

On the other hand, reduced tolerance to effort is often the result of an impaired pulmonary function, but misinterpreted as a coronary symptom, whereas short-breath may be misinterpreted as a manifestation of congestive heart failure. Thus, pulmonary disease in patients with known cardiovascular disease often remains unrecognized (30). Bearing in mind the fact that noninvasive diagnostic procedures, such as echocardiographic stress tests, in 
patients with advanced stages of COPD have significant limitation, the missed diagnosis of Coexisting COPD in CAD is not a rarity (31). The unrecognized and missed diagnosis of bronchial obstruction by type of COPD in patients with CAD ranges between $60-87 \%$ of patients, especially in the population of former smokers that have milder respiratory symptoms and lower stage of lung ventilation disorders (32).

Considering the complexity of the cardiopulmonary continuum, in the clinical work it is necessary to carry out additional tests. The investigation of pulmonary function in a euvolemic patient is indispensable, such as the inevitable echocardiographic examination when there is a suspicion of cardiovascular comorbidity (33). With this in mind, it is necessary for each patient with COPD to be actively and thoroughly examined for potential coexisting CAD; functional lung testing is of great importance in patients with CAD as well.

\section{Therapeutic approach}

Acute exacerbations of COPD can be the triggers of acute cardiovascular events; however, they can be triggered by previous cardiovascular events. Despite an improved diagnostic-therapeutic procedure, this two-way association often remains unrecognized. The effect of COPD treatment (based on $\beta 2$-agonists, anticholinergics, inhaled corticosteroids, and phosphodiesterase-4 inhibitors) on the coexisting vulnerability of the cardiovascular system is still not fully understood.

Tachycardia is an independent risk factor for cardiovascular mortality in the general population, so uncontrolled use of bronchodilators in acute exacerbation of COPD can theoretically aggravate the coexisting cardiovascular disease. The results of the studies on this topic are not sufficient for a reliable conclusion. Comparison of side effects of short-acting $\beta 2$-agonists and short-acting anticholinergics (on heart rate and arterial blood pressure) in patients with stable COPD did not show a statistically significant difference (34). The difference between the incidence of supraventricular arrhythmias in patients using ipratropium in comparison to placebo also was not statistically significant (35). Thus, data confirming the undesirable effects of short-acting bronchodilators on cardiovascular comorbidities is missing.
Corticosteroids are known to exacerbate hypertension, hyperlipidemia and glucose intolerance, the most common risk factors for CAD. In patients using inhaled corticosteroid (ICS) therapy, there is a higher stage of COPD, and consequently a greater risk for the occurence and development of CAD. The use of ICS at low doses (equivalent to daily doses of 50-200 $\mu \mathrm{gr}$ of Beclomethason) is significantly associated with a reduced risk of acute coronary syndrome, but the effect of the cortico-steroid therapy on the cardiovascular system is dosedependent (36).

The most noticeable difference in treatment strategies for COPD and CAD exists with regard to the use of $\beta 2$-agonists in COPD, on the one hand, and $\beta$-blockers in heart disease, on the other hand. The results are contradictory indications and the consequent reduced use of these medicines, especially $\beta$-blockers. The data indicate that long-acting $\beta 2$-agonists are better tolerated and have more acceptable safety profile in cardiovascular patients, and do not increase the risk of cardiovascular events, as confirmed by TORCH study results (37). On the other side, according to the results of SUMMIT study, the use of $\beta$-blockers, as the cornerstone of CAD treatment in patients with COPD, remains controversial (38) except for cardioselective $\beta$ blockers which have a significant advantage in the treatment and reduction of the mortality rate in patients with COPD and coexisting CAD, without chronic respiratory failure (39-40).

Antiaggregation therapy has significant implications for reducing mortality in COPD patients older than 45 years, as well as those with chronic respiratory failure and long-term oxygen therapy (41).

Having in mind low-grade chronic systemic inflammation as a common pathophysiological mechanism, the pleotropic anti-inflammatory effect of statins, medicines widely used in patients with CAD, is also significant in patients with COPD. The results of the Rotterdam study just prove that statin therapy is significantly associated with reduced mortality in patients with concomitant COPD (42).

The effect of angiotensin-converting enzyme inhibitors (ACEI) and angiotensin receptor blockers (ARBs) had already been known. The use of these drugs is directly related to a lower mortality rate in patients with COPD and CHD, which is not the result of an isolated reduction in cardiovascular mor- 
tality only (43). The positive effect of these drugs on reducing the number of hospitalizations due to acute exacerbation of COPD was observed only in concomitant use with statins (44). Further studies are needed to confirm the effect of these drugs on respiratory and cardiovascular morbidity and mortality in patients with COPD.

In addition to medication therapy, physical training and rehabilitation procedures also significantly reduce the morbidity and mortality of CAD and COPD, as they result in an increase in the functional capacity of the heart and lungs, by reducing the demands of daily metabolic activities and lowering the pulse frequency and blood pressure values. On the other hand, these procedures reduce body weight and increase muscle mass; the total serum cholesterol levels are decreased, and the lowdensity lipoprotein (LDL) fraction is increased; platelet adherence is reduced, with faster and better fibrinolysis, and reduced overall adrenergic response to stress. In addition, lifestyle change and reducing risk factors have a synergistic beneficial effect on the cardiovascular and respiratory system. A compara- tive analysis of the effects of these programs in various EU-wide surveys, as a part of INTERHEARTH study, showed reduction in the risk of subsequent CAD mortality by $20 \%$ and a risk of hospitalization due to acute exacerbation of COPD by $25 \%$ (45).

\section{CONCLUSION}

Clinical manifestations of cardiovascular comorbidities in COPD are consequently underestimated in routine clinical practice, and low-grade chronic systemic inflammation, as a common pathogenetic link in the chain of the living and working environment air pollution and impact of smoking, leads to significant damage to both bronchial mucosal epithelium and vascular endothelium.

Despite the reliable evidence confirming the link between COPD and cardiovascular disease, modern therapeutic options for targeted treatment of these diseases are still in the testing phase, with no more relevant randomized clinical trials in this field. The first results of the SUMMIT study promise a more appropriate treatment of these patients. 


\section{References}

1. Singh D, Agusti A, Anzueto A, et al. Global Strategy for the Diagnosis, Management, and Prevention of Chronic Obstructive Lung Disease: the GOLD science committee report 2019. Eur Respir J 2019; 53(5): pii: 1900164. https://doi.org/10.1183/13993003.00164-2019

2. Radovic M, Ristic L, Ciric Z, et al. Changes in respiratory function impairment following the treatment of severe pulmonary tuberculosislimitations for the underlying COPD detection. Int J Chron Obstruct Pulmon Dis 2016; 11(1): 1307-16. https://doi.org/10.2147/COPD.S106875

3. Stanković I, Ćirić Z, Radović M. Asthma exacerbations and viruses. Acta Fac Med Naiss 2011; 28(4): 241-4. UDC:616.211-002:616.248

4. Hogg JC, Timens W. The pathology of chronic obstructive pulmonary disease. Annu Rev Pathol 2009; 4: 435-59.

https://doi.org/10.1146/annurev.pathol.4.110807.09 $\underline{2145}$

5. Mullerova H, Agusti A, Erqou S, et al. Cardiovascular comorbidity in chronic obstructive pulmonary disease: systematic literature review. Chest 2013; 144: 1163-78 https://doi.org/10.1378/chest.12-2847

6. Finkelstein J, Cha E, Scharf SM. Chronic obstructive pulmonary disease as an independent risk factor for cardiovascular morbidity. Int J Chron Obstruct Pulmon Dis 2009; 4: 337-49.

\section{https://doi.org/10.2147/COPD.S6400}

7. Cui H, Miao DM, Wei MZ, et al. Prevalence of cardiovascular disease in subjects hospitalized due to chronic obstructive pulmonary disease in Beijing from 2000 to 2010. J Geriatr Cardiol 2012; 9(1): 5-10.

https://doi.org/10.3724/SP.J.1263.2012.00005
8. Quint J. The Relationship between COPD and Cardiovascular Disease. Tanaffos 2017; 16(Suppl 1): S16-S17. PMID: 29158754

9. Ford ES, Wheaton AG, Mannino DM, et al. Elevated cardiovascular risk among adults with obstructive and restrictive airway functioning in the United States: a cross-sectional study of the National Health and Nutrition Examination Survey from 2007-2010. Respir Res 2012; 13(1): 115.

https://doi.org/10.1186/1465-9921-13-115

10. Bursi F, Vassallo R, Weston SA, et al. Chronic obstructive pulmonary disease after myocardial infarction in the community. Am Heart J 2010; 160(1): 95-101.

https://doi.org/10.1016/j.ahj.2010.05.004

11. Cao C, Wang R, Wang J, et al. Body mass index and mortality in chronic obstructive pulmonary disease: a meta-analysis. PLoS One 2012; 7: 1-8. https://doi.org/10.1371/journal.pone.0043892

12. Ciric Z, Stankovic I, Pejcic T, et al. Nutrition disorders and systemic inflamation in patients with chronic obstructive pulmonary disease. Med Glas 2013; 10(2): 266-71. PMID: 23892843

13. Diez-Manglano J, Barquero-Romero J, Almagro P, et al. COPD patients with and without metabolic syndrome: clinical and functional differences. Intern Emerg Med 2014; 9(4): 419-25. https://doi.org/10.1007/s11739-013-0945-7

14. Yuji H, Toshiyuki Y, Noritsugu H, et al. Clinical and inflammatory factors associated with body mass index in elderly patients with chronic obstructive pulmonary disease. Geriatr Gerontol Int 2011; 11(1): 32-8.

https://doi.org/10.1111/j.1447-0594.2010.00629.x 
15. O'Donnell CJ, Elosua R. Cardiovascular risk factors. Insights from framingham heart study. Rev Esp Cardiol 2008; 61(3): 299-310. https://doi.org/10.1016/S1885-5857(08)60118-8

16. Poulain M, Doucet M, Major GC, et al. The effect of obesity on chronic respiratory diseases: pathophysiology and therapeutic strategies. CMAJ 2006; 174: 1293-9.

https://doi.org/10.1503/cmaj.051299

17. Camiciottoli G, Bigazzi F, Magni C, et al. Prevalence of comorbidities according to predominant phenotype and severity of chronic obstructive pulmonary disease. Int J Chronic Obstruct Pulm Dis 2016; 11: 2229-36.

https://doi.org/10.2147/COPD.S111724

18. Schnell K, Weiss CO, Lee T, et al. The prevalence of clinically-relevant comorbid conditions in patients with physician-diagnosed COPD: a crosssectional study using data from NHANES 19992008. BMC Pulm Med 2012; 12: 26.

https://doi.org/10.1186/1471-2466-12-26

19. Morgan AD, Zakeri R, Quint JK. Defining the relationship between COPD and CVD: what are the implications for clinical practice? Ther Adv Respir Dis 2018; 12: 1-16.

https://doi.org/10.1177/1753465817750524

20. Marchetti N, Ciccolella DE, Jacobs MR, et al. Hospitalized acute exacerbation of COPD impairs flow and nitroglycerin mediated peripheral vascular dilation. COPD 2011; 8(2): 60-5. https://doi.org/10.3109/15412555.2011.558541

21. Van Eeden SF, Sin DD. Chronic obstructive pulmonary disease: a chronic systemic inflammatory disease. Respiration 2008; 75(2): 224-38.

https://doi.org/10.1159/000111820

22. Sevenoaks MJ, Stockley RA. Chronic obstructive pulmonary disease, inflammation and co-morbiditya common inflammatory phenotype. Respir Res 2006; 7: 70 .

https://doi.org/10.1186/1465-9921-7-70
23. Kido T, Tamagawa E, Bai N, et al. Particulate matter induces translocation of IL-6 from the lung to the systemic circulation. Am J Respir Cell Mol Biol 2011; 44(2): 197-204. https://doi.org/10.1165/rcmb.2009-0427OC

24. Roversi S, Roversi P, Spadafora G, et al. Coronary artery disease concomitant with chronic obstructive pulmonary disease. Eur J Clin Invest 2014; 44 (1): 93-100. https://doi.org/10.1111/eci.12181

25. Garcia-Olmos L, Alberquilla A, Ayala V, et al. Comorbidity in patients with chronic obstructive pulmonary disease in family practice: a cross sectional study. BMC Fam Pract 2013; 14: 11. https://doi.org/10.1186/1471-2296-14-11

26. Divo M, Cote C, De Torres JP, et al. Comorbidities and risk of mortality in patients with chronic obstructive pulmonary disease. Am J Respir Crit Care Med 2012; 186(2): 155-61. https://doi.org/10.1164/rccm.201201-0034OC

27. De Lucas-Ramos P, Izquierdo-Alonso JL, RodriguezGonzalez Moro JM, et al. Cardiovascular risk factors in chronic obstructive pulmonary disease: results of the ARCE study. Arch Bronconeumol 2008; 44: 233-8.

https://doi.org/10.1157/13119937

28. Bertoletti L, Quenet S, Mismetti P, et al. Clinical presentation and outcome of venous thromboembolism in COPD. Eur Respir J 2012; 39: 862-8.

https://doi.org/10.1183/09031936.00058811

29. Brekke PH, Omland $\mathrm{T}$, Smith $\mathrm{P}$, et al. Underdiagnosis of myocardial infarction in COPD - Cardiac Infarction Injury Score (CIIS) in patients hospitalised for COPD exacerbation. Respir Med 2008; 102: 1243-7.

https://doi.org/10.1016/j.rmed.2008.04.010

30. Boschetto P, Beghe B, Fabbri LM, et al. Link between chronic obstructive pulmonary disease and coronary artery disease: implication for clinical practice. Respirology 2012; 17: 422-31. https://doi.org/10.1111/j.1440-1843.2011.02118.x 
31. Reed RM, Eberlein M, Girgis RE, et al. Coronary artery disease is under-diagnosed and undertreated in advanced lung disease. Am J Med 2012; 125(12): 1228.e13-1228.e22.

https://doi.org/10.1016/j.amjmed.2012.05.018

32. Roca M, Verduri A, Corbetta L, et al. Mechanisms of acute exacerbation of respiratory symptoms in chronic obstructive pulmonary disease. Eur J Clin Invest 2013; 43: 510- 21.

https://doi.org/10.1111/eci.12064

33. McMurray JJ, Adamopoulos S, Anker SD, et al. ESC guidelines for the diagnosis and treatment of acute and chronic heart failure 2012: The Task Force for the Diagnosis and Treatment of Acute and Chronic Heart Failure 2012 of the European Society of Cardiology. Developed in collaboration with the heart failure association (HFA) of the ESC. Eur Heart J 2012; 33(14): 1787-1847. https://doi.org/10.1093/eurheartj/ehs104

34. Appleton $\mathrm{S}$, Jones $\mathrm{T}$, Poole $\mathrm{P}$, et al. Ipratropium bromide versus short acting beta-2 agonists for stable chronic obstructive pulmonary disease. Cochrane Database Syst Rev 2006; (3): CD001387. https://doi.org/10.1002/14651858.CD006101

35. Anthonisen NR, Connett JE, Enright PL, et al. Hospitalizations and mortality in the lung health study. Am J Respir Crit Care Med 2002; 166(3): 333-9.

https://doi.org/10.1164/rccm.2110093

36. Huiart L, Ernst P, Ranoui X, et al. Low-dose inhaled corticosteroids and the risk of acute myocardial infarction in COPD. Eur Respir J 2005; 25: 634-9. https://doi.org/10.1183/09031936.05.00079004

37. Calverley PMA, Anderson JA, Celli B, et al.. Cardiovascular events in patients with COPD: TORCH Study results. Thorax 2010; 65: 719-25. https://doi.org/10.1136/thx.2010.136077

38. Vestbo J, Anderson J, Brook RD, et al. The Study to Understand Mortality and Morbidity in COPD
(SUMMIT) study protocol. Eur Respir J 2013; 41: 1017-22. https://doi.org/10.1183/09031936.00087312

39. Etminan M, Jafari S, Carleton B, et al. Beta-blocker use and COPD mortality: a systematic review and meta-analysis. BMC Pulm Med 2012; 12: 48. https://doi.org/10.1186/1471-2466-12-48

40. Decramer ML, Hanania NA, Lotvall JO, et al. The safety of long-acting beta2-agonists in the treatment of stable chronic obstructive pulmonary disease. Int J Chron Obstruct Pulmon Dis 2013; 8: 53-64.

https://doi.org/10.2147/COPD.S39018

41. Donaldson GC, Hurst JR, Smith CJ, et al. Increased risk of myocardial infarction and stroke following exacerbation of COPD. Chest 2010; 137(5): 1091-7. https://doi.org/10.1378/chest.09-2029

42. Lahousse L, Loth DW, Joos GF, et al. Statins, systemic inflammation and risk of death in COPD: the Rotterdam study. Pulm Pharmacol Ther 2013; 26: 212-17.

https://doi.org/10.1016/j.pupt.2012.10.008

43. Mortensen EM, Copeland LA, Pugh MJV, et al. Impact of statins and ACE inhibitors on mortality after COPD exacerbations. Respir Res 2009; 10: 45. https://doi.org/10.1186/1465-9921-10-45

44. Mancini GBJ, Etminan M, Zhang B, et al. Reduction of morbidity and mortality by statins, angiotensin-converting enzyme inhibitors, and angiotensin receptor blockers in patients with chronic obstructive pulmonary disease. J Am Coll Cardiol 2006; 47(12): 2554-60.

https://doi.org/10.1016/j.jacc.2006.04.039

45. Held C, Iqbal C, Lear SA, et al. Physical activity levels, ownership of goods promoting sedentary behaviour and risk of myocardial infarction: results of the INTERHEART study. Eur Heart J 2012; 33(4): 452-66. doi: 10.1093/eurheartj/ehr432 https://doi.org/10.1093/eurheartj/ehr432 


\title{
Klinički relevantni obrasci kardiovaskularnih komorbiditeta kod bolesnika sa HOBP: da li su uopšte važni?
}

\author{
Borislav Božanić ${ }^{1,4}$, Milan Radović, ${ }^{1,2,4}$, Ivana Stanković1,4, Svetlana Apostolovićs,4, \\ Tatjana Pejčići, ${ }^{1,4}$ Zorica Ćirić1,4, Lidija Risitić1,4, Milan Rančić1, ${ }^{1,4}$ \\ ${ }^{1}$ Klinika za plućne bolesti, Klinički centar Niš, Niš, Srbija \\ ${ }^{2}$ Klinika za grudnu hirurgiju, Klinički centar Niš, Niš, Srbija \\ ${ }^{3}$ Klinika za kardiovaskularne bolesti, Klinički centar Niš, Niš, Srbija \\ ${ }^{4}$ Univerzitet u Nišu, Medicinski fakultet, Niš, Niš, Srbija
}

\section{SAŽETAK}

Udruženost hronične opstruktivne bolesti pluća (HOBP) i kardiovaskularnih bolesti uočena je tokom proučavanja sistemskih posledica ove bolesti. Među obolelima, značajno je veća incidencija, a veći je i mortalitet od kardiovaskularnih bolesti, dok redukcija kardiovaskularnog rizika predstavlja važno polje za smanjenje sveukupnog mortaliteta od HOBP. Kompleksni patofiziološki mehanizmi interakcije respiratornog sistema i kardiovaskularnog sistema, tokom akutizacije HOBP još uvek nisu dovoljno proučeni, a njihova klinička ispoljavanja predstavljaju sve veći izazov u savremenoj dijagnostici i terapiji. Studije pokazuju to da intenziviranje sistemskog inflamatornog odgovora u akutnoj egzacerbaciji HOBP rezultira endotelnom disfunkcijom, aktivacijom aterosklerotskih plakova, većom podložnošću ka formiranju tromba i rupturi, što je posredan, ali veoma značajan uzrok akutnih kardiovaskularnih događaja. Akutna pogoršanja HOBP mogu biti okidači za akutni kardiovaskularni događaj, ali mogu i sama biti pokrenuta prethodnim kardiovaskularnim dešavanjem. Uprkos unapređenim dijagnostičko-terapijskim postupcima, ova dvosmerna povezanost često ostaje neprepoznata. Efekat tretmana HOBP na koegzistirajuću vulnerabilnost kardiovaskularnog sistema još uvek nije u potpunosti razjašnjen. I pored sigurnih dokaza, koji potkrepljuju vezu između HOBP i kardiovaskularnih bolesti, savremene terapijske opcije ciljanog lečenja ovih bolesti još uvek su u fazi istraživanja, bez relevantnijih randomizovanih kliničkih ispitivanja na ovu temu. Prvi rezultati SUMMIT studije obećavaju adekvatniji tretman ovih bolesnika.

Ključne reči: hronična opstruktivna bolest pluća, kardiovaskularni komorbiditeti, hronična inflamacija 